\title{
m LLIITTS
}

35.2.2019 [195-218]

\section{KOMUNIKASI KRISTIANI: MELAWAN DESAKRALISASI DIRI DI MEDIA SOSIAL}

\author{
Yanuarius Muni | Graduate Student of Theology \\ Faculty of Philosophy \\ Parahyangan Catholic University \\ Bandung, Indonesia
}

\begin{abstract}
:
Fake news spreads quickly and changes situations in the society. It has become a sort of linguistic violence circulating negative ideologies and perspectives that slowly destroy people both mentally and physically. The growing tendency of circulating fake news raises a serious problem in the society and moreover among Christians, for important human values, including religious values, are disregarded. Christian understanding of human beings as created in the image of God implies that they have the capacity to use good words to build a sacred society, that is, a society blessed by God. However, the tendency to retrieve and to disseminate information too quickly occurs almost automatically in this age of information, which ironically threatens every good intention of the self in building a trusting community. This article explores the elements of Christian communication based on the Church teachings on the subject matter, in order to counter the tendency of desacralisation of the self on social media and to promote truthful as well as deliberating communication in the society.
\end{abstract}

Keywords:

communication etbics - Christian communication - fake news - self • desacralisation • sacred community 


\section{Introduksi}

Di tengah kemajuan ilmu pengetahuan dan teknologi, masyarakat Indonesia semakin hari semakin menjadi Masyarakat Informasi. Masyarakat semakin banyak mengakses media komunikasi dalam pelbagai jenis sekaligus menjadi pelaku aktif komunikasi. Kemajuan media elektronik yang sangat pesat menembus batas ruang dan waktu kehidupan manusia dan menyebarkan bermacam-macam informasi hampir seketika. Sementara itu, masyarakat Indonesia pun mengalami penurunan kualitas dalam hal kultur tulis-cetak-baca yang lebih reflektif. Masyarakat semakin dipengaruhi arus budaya audio-visual modern yang mumpuni. Lompatan jauh dari model tradisional ke model elektronis yang menggunakan teknologi audio-visual, membuat masyarakat cenderung pasif sekaligus konsumtif terhadap informasi. Artinya, masyarakat pun cenderung tidak menggunakan kemampuan dan kesempatan untuk menelaah informasi secara kritis, sehingga publik menjadi sasaran manipulasi. ${ }^{1}$ Dunia maya, dengan aneka ambiguitasnya terus berkembang menembus sekat-sekat kultural manusia. Di sini juga media sosial berubah menjadi seperti ruang manipulatif yang merupakan tempat segala hal bisa diputarbalikkan. Data dan fakta bisa direkonstruksi sedemikian rupa hingga sulit untuk menentukan kebenarannya.

Di ranah ini, manusia dihadapkan pada beragam pilihan terutama dalam penggunaan media teknologi informasi. Berita yang beredar menyulitkan pembedaan antara fakta dan manipulasi yang saling berkelindan, tumpang-tindih, dan inkonsisten. Keputusan etis mesti disertakan dalam setiap tanggapan manusia atas meriapnya kebohongan di media informasi dalam berbagai bentuknya yang muncul di media sosial. Keputusan etis yang dimaksud adalah perkara menjaga integritas diri (self) ketika berhadapan dengan berbagai persoalan yang kontradiktif dalam teknologi informasi.

Terkait dengan masifnya bentuk-bentuk kebohongan di berbagai media sosial, tulisan ini hendak menelaah hubungan antara 'hoaks' (informasi bohong) dan panggilan kristiani untuk menjaga sakralitas diri dalam sudut pandang teologis. Telaah ini dimaksud sebagai suatu tawaran 
reflektif bagi manusia pada umumnya dan umat kristiani khususnya, agar mampu menjadi pribadi yang kritis-reflektif dalam mengakses dan menyebarkan informasi, sebagaimana diserukan Dewan Kepausan untuk Komunikasi Sosial ("Gereja dan Internet" dan "Etika dalam Internet") ${ }^{2}$ dan Surat Apostolik Paus Yohanes Paulus II ("Perkembangan Cepat") untuk mengkomunikasikan kebaikan dan kebenaran sebagai cerminan panggilan manusia sebagai rekan kerja Allah di dunia.

\section{Desakralisasi Diri dalam Penyebaran Hoaks}

Isu tentang hoaks berseliweran di tengah masyarakat dalam berbagai bentuk, baik secara global, nasional, maupun lokal. Dalam konteks politik Amerika, misalnya, setelah Donald Trump terpilih menjadi presiden disinyalir terdapat praktik-praktik kebohongan dalam memengaruhi publik Amerika yang mengantar kepada kemenangannya. Persoalan yang senada juga ditemukan di Inggris dalam kasus 'Brexit' ("British Exit"), ketika Inggris keluar dari Uni Eropa karena elit politiknya membuat berita bohong serta membujuk anggota parlemen untuk keluar dari Eropa dan stabilitas ekonomi politiknya pun terancam dalam sepanjang sejarah. Menguatnya hoaks di Indonesia dapat dilacak kembali pada beberapa tahun terakhir, yakni pada pemilihan Pilkada DKI pada 2017 yang melibatkan manipulasi video yang menampilkan salah satu calon dan yang kemudian tersebar luas. ${ }^{4}$ Di Indonesia, Kepolisian mencatat bahwa setiap hari kurang lebih disebarkan 3.500 berita palsu. Intensitas berita palsu meningkat dalam situasi kampanye politik. Hoaks politik dalam hal ini adalah berita bohong yang menyerang calon pemimpin politik, partai politik peserta Pemilu, KPU dan Bawaslu. Ketidakbenaran informasi tersebut memantik kerusuhan dan bentrokan massa. ${ }^{5}$

Sejumlah fenomena di atas menunjukkan bahwa hoaks menyebar dengan sangat cepat dan memperkeruh situasi di masyarakat. Hoaks bisa disebut sebuah aksi kekerasan bahasa, yang bukan bersifat langsung, namun melalui ideologi dan perspektif, serta bisa menghancurkan fisik dan mental seseorang atau sekelompok masyarakat secara perlahan-lahan. Masyarakat dunia kini rentan menerima informasi-informasi yang manipulatif dan menyesatkan. Setiap orang bisa terpapar dan bahkan membuat hoaks itu sendiri. Kehidupan masyarakat yang diwarnai hiperkoneksi menyebabkan hoaks tumbuh subur di era pasca-kebenaran. Dalam hal ini, kebenaran 
menjadi sesuatu yang kabur dan emosi lebih dikedepankan daripada objektivitas. Muncul kesulitan membedakan fakta dan bukan fakta. Semua bercampur menjadi satu sehingga mengaburkan fakta dan peristiwa yang otentik. $^{6}$

Kurangnya sikap kritis dalam mengindentifikasi kebenaran berita dapat menimbulkan petaka bagi diri sendiri dan orang lain. Hoaks memengaruhi berbagai bidang kehidupan, baik politik, ekonomi, budaya, maupun agama. Hoaks adalah ibarat penyakit yang timbul tanpa dapat dikendalikan dan menyebar lewat aliran informasi. Dalam situasi ini, setiap orang dituntut untuk lebih kritis, serta melihat realitas dengan jernih dan rasional. Hal ini penting sebab di era keterbukaan informasi dengan aneka ketidakpastian berita, yang juga sering terlampau simpang siur, bisa menjadi kabut pekat yang menutup kejernihan pandangan dalam memilah benar-tidaknya suatu informasi. Sikap reaktif berlebihan dan mudah diprovokasi tanpa terlebih dahulu memastikan kebenaran berita bisa semakin membutakan pikiran dan hal ini tidak menutup kemungkinan hingga berujung pada kekerasan. 'Desakralisasi' diri tecermin dalam perilaku yang membiarkan diri tidak membawa atau menyampaikan kebenaran, yang dalam hal ini dilakukan oleh penyebar hoaks.

\section{Perkembangan Pemahaman tentang Hoaks}

Menurut Kamus Besar Bahasa Indonesia (KBBI), hoaks diartikan sebagai berita bohong. Dalam Oxford English Dictionary, hoaks didefinisikan sebagai "malicious deception" atau "kebohongan yang dibuat dengan tujuan jahat". Hoaks juga didefinisikan sebagai informasi yang sesungguhnya tidak benar, tetapi dibuat seolah-olah benar. Hal ini tidak sama dengan rumor, ilmu semu, maupun istilah "April Mop".7 Hoaks merupakan informasi palsu atau berita yang sebenarnya bisa memuat fakta, namun telah direkayasa. Informasi palsu ini dikemas sedemikian rupa sehingga jika tidak disertai dengan keseriusan menyimak, orang akan dengan gampang percaya pada kebohongan atau kekeliruan. Di masa kini, telepon genggam sudah dilengkapi dengan berbagai jenis aplikasi dan juga beragam petunjuk yang semakin memudahkan orang untuk merekayasa berita. Sikap mawas diri dituntut karena hoaks membawa pretensi untuk merusak pandangan orang lain. Istilah "berita palsu" menjadi objek diskusi global dewasa ini, secara khusus mengacu pada penyebaran informasi 'daring' atau juga 
informasi di media massa 'luring'. Hal ini berkaitan dengan informasi yang tidak berdasarkan data atau yang telah direkayasa dengan tujuan menipu dan mengelabui pembaca.

Dalam lingkup Gereja Katolik, pada perayaan Hari Komunikasi 2018, di bawah tema "Kebenaran itu akan Memerdekakan Kamu (Yoh 8:32): Berita Palsu dan Jurnalisme Perdamaian”, Paus Fransiskus mendefinisikan hoaks ("fake news") sebagai tindakan menyebarkan disinformasi, baik secara daring maupun luring, dengan cara memanipulasi kebenaran informasi sehingga dapat mengecoh pembaca. Tindakan menduplikasi informasi ini dikemas dalam berbagai bentuk sehingga tampaknya masuk akal atau meyakinkan, dan mampu menarik perhatian karena memunculkan kesan publik tentang hal-hal yang ingin diketahui masyarakat serta mengeksploitasi emosi sesaat, seperti kecemasan, kemarahan, keterhinaan, dan frustrasi. Berita bohong cenderung mendeskreditkan orang lain, menempatkan orang lain sebagai musuh, sampai pada titik yang menjelekkan sehingga menimbulkan konflik. Berita bohong menampilkan sikap intoleran dan hipersensitif dan hanya bertujuan menunjukkan arogansi dan menyebar kebencian. Hal-hal itu merupakan hasil dari beritaberita yang tidak benar. ${ }^{8}$

\section{Asal-Usul Kata Hoaks}

Menurut filolog Robert Nares (1753-1829), kata hoax mulai dipakai di Inggris pada Abad ke-18. Dalam bukunya A Glossary, Nares menulis bahwa hoax berasal dari hocus, sebuah kata Latin yang merujuk pada bocus pocus. Pada lema kata hocus, Nares menambahkan arti "to cheat" atau 'menipu'. Hocus pocus, menurut Nares, mengacu pada mantra para penyihir yang kemudian dipakai para pesulap ketika memulai trik mereka. Hocus pocus diambil dari nama penyihir Italia yang terkenal, yakni Ochus Bochus. Pengertian "to cheat" di sini ditujukan untuk mengacaukan orang lain demi hiburan belaka."

Lynda Walsh dalam bukunya Sins against Science mengatakan bahwa hoaks merupakan istilah Bahasa Inggris yang mulai masuk sejak era industri pada 1808. Akan tetapi, asal kata hoaks diyakini sudah ada dan muncul ratusan tahun sebelumnya, dari kata hocus pocus yang merujuk ke kata 'apokrif' (apocrypha), berasal dari kata apokryphos dalam Bahasa Yunani, artinya 'rahasia' atau 'tersembunyi'. Walsh memberikan perbandingan 
terkait dengan frase hoc est corpus, dalam keyakinan transubstansiasi (dalam Gereja Katolik: perubahan roti dan anggur yang digunakan dalam perayaan Ekaristi menjadi Tubuh dan Darah Kristus). Menurut pandangan Walsh, istilah hocus pocus memunculkan alusi pada frase hoc est corpus ${ }^{10}$ yang membuat orang meragukan kebenarannya apabila tidak mengimaninya. ${ }^{11}$

\section{Kemunculan Hoaks di Indonesia}

Hoaks adalah informasi yang direkayasa untuk menutupi informasi sebenarnya. Hoaks dibuat seseorang atau suatu kelompok dengan beragam tujuan, mulai dari maksud membuat lelucon hingga terkait aspek-aspek penting dalam kehidupan. Hoaks dibuat agar khalayak ramai tidak lagi terfokus pada masalah sebenarnya, dan akan terjebak pada hal-hal bombastis yang bukan merupakan permasalahan pokok. Dengan pengetahuan masyarakat yang terbatas dan kurangnya sikap kritis serta keseriusan dalam mengolah informasi, penggiringan opini melalui berita bohong mudah tersebar luas. Faktor utama yang menyebabkan informasi palsu mudah tersebar di Indonesia adalah karakter masyarakat Indonesia yang dinilai belum terbiasa berpendapat secara sehat. ${ }^{12}$

Selain karena sifat hoaks yang sensasional, faktor sosial budaya setempat juga turut memengaruhi beredar luasnya hoaks, seperti kurangnya literasi, rendahnya budaya membaca, serta kegemaran dalam berbagi berita dan gosip. Di Indonesia persoalan ini cukup menentukan. UNESCO menyebutkan bahwa Indonesia berada pada urutan kedua dari bawah dalam hal literasi di dunia, mengacu pada minat baca yang sangat rendah. Menurut data UNESCO, minat baca masyarakat Indonesia sangat memprihatinkan, yakni hanya 0,001 persen. Artinya, dari seribu orang Indonesia, cuma satu orang yang rajin membaca. ${ }^{13}$ Keresahan yang dialami bangsa Indonesia juga merupakan keresahan yang bersifat global. Dalam lingkup Gereja Katolik, Paus Fransiskus merasa prihatin terhadap mudahnya penyebaran berita bohong. Menurut Paus, penyebaran berita palsu di media daring ("dalam jaringan") dan cetak telah menimbulkan kebingungan dan kecemasan di hati umat manusia. Lebih dari itu, penyebaran ini memengaruhi opini publik untuk mempercayai kepalsuan daripada kebenaran. Hal yang tidak benar menjadi seolah-olah benar. Sebaliknya, hal yang benar dimanipulasi sehingga menjadi tidak benar. Berita palsu menyebar dengan cepat, menjadi tersebar sangat luas secara 
cepat dan sulit dihentikan, dan hal itu bukan karena tingginya semangat berbagi sebagaimana kecenderungan di media sosial, melainkan karena terpicunya keserakahan atau egoisme dalam diri manusia yang cenderung tidak pernah terpuaskan. ${ }^{14}$

\section{Hoaks Dalam Perspektif Teologis}

Tidak terhindarkan bahwa umat kristiani bisa tersangkut pada jejaring kekerasan verbal melalui internet dan berbagai forum komunikasi digital. Bahkan, di dalam forum-forum Katolik sekalipun, ada gejala bahwa fitnah dan umpatan diberi tempat, sementara etika berkomunikasi dan rasa hormat terhadap nama baik orang lain diabaikan. Hasilnya adalah dikotomi yang berbahaya dalam kesadaran diri, karena di dalam forum-forum itu disampaikan apa yang lazimnya tidak dapat diterima dalam perbincangan publik, dan orang pun berusaha mengkompensasi ketidakpuasannya dengan kemarahan dan reaksi karena kebencian. Terkadang demi tujuan pribadi atau kelompok tertentu, orang bisa menyangkal perintah kedelapan yang berbunyi "Jangan bersaksi dusta", dan selanjutnya menghina sesama manusia dengan cara yang kasar. Di sini seakan-akan terjadi peringatan dalam Surat Yakobus bahwa lidah pun adalah "dunia kejahatan" yang dapat "menyalakan roda kehidupan kita, sedang ia sendiri dinyalakan oleh api neraka" (Yak. 3:6). ${ }^{15}$

Injil Matius 15:11 mengingatkan umat kristiani untuk mendengar dan mencamkan bahwa bukan yang masuk ke dalam mulut yang menajiskan orang, melainkan yang keluar dari mulut; itulah yang menajiskan orang. Pengertian tentang kenajisan membuat diri kotor, tercemar, tidak bersih, dan tidak suci, namun bukan pertama-karena makanan, melainkan karena maksud jahat dari tuturan. Kenajisan dalam hal ini tampak sebagai desakralisasi diri manusia. Pembacaan konteks Injil Matius itu bisa diarahkan pada kata-kata tidak baik yang diucapkan melalui media sosial, yang salah satunya berupa berita bohong, dan itulah yang menajiskan diri manusia. Kenajisan tidak berasal dari luar diri manusia, tetapi bersumber dari dalam dirinya. Hati manusia dapat menajiskan dirinya dan hidupnya, yakni ketika memunculkan pikiran, perkataan, dan perbuatan yang najis di mata Allah. Oleh karena itu, hati harus dijaga, sebab kelalaian dalam usaha ini berakibat pada tendensi menajiskan. Dalam hal melawan kebohongan, Agustinus pernah mengungkapkan perlunya menjaga keharmonisan hati 
dan mulut. ${ }^{16}$ Sementara itu, Paulus mengingatkan bahwa dengan hati orang percaya (Rm. 10:10). Hati adalah inti diri manusia, tempat semua dimensi yang berbeda saling terkait satu sama lain, yakni tubuh dan roh, ruang batin dan keterbukaan pada dunia serta sesama, intelektualitas, kehendak dan afektivitas. ${ }^{17}$ Ketika hati dijaga agar tidak tercemar oleh kecenderungan buruk, orang akan menjadi lebih terbuka pada kebenaran dan kasih. Kebenaran dan kasih ini berdaya guna mengubah diri seseorang. Menjaga hati tetap bersih dari segala hal yang menodai kasih membawa pada kekudusan, ${ }^{18}$ dan di sini ditemukan pengertian 'sakralisasi' diri.

Dalam Kitab Suci Perjanjian Lama, Yesaya merenungkan bahwa Tuhan Allah telah memberikan kepadanya lidah seorang murid, supaya dengan perkataan ia dapat memberi semangat baru kepada orang yang letih lesu. Setiap pagi Tuhan mempertajam pendengarannya untuk mendengar seperti seorang murid (Yes. 50:4). Seorang murid yang baik, karenanya, akan bersikap santun dalam berkata-kata. Lidahnya akan dijaga, karena dengan lidah orang bisa memuji Allah, berdoa, berkata-kata baik dan benar, serta jujur dan tulus. Akan tetapi, dengan lidah juga orang bisa berkata kasar, memfitnah, berbohong, dan bersaksi dusta. Belajar dari permenungan Yesaya, yang mendapatkan lidah dan telinga seorang murid, yang setia dan taat kepada kehendak Allah dalam melaksanakan tugas kenabiannya, setiap orang Kristen pun diundang untuk melaksanakan tugas kenabiannya. Umat Kristen diundang untuk selalu berada dalam komitmen ini, yakni komitmen pada kebenaran di tengah kultur informasi kini. Media komunikasi sosial, dalam hal ini, harus digunakan dengan baik dan bijaksana, benar dan bertanggung jawab, tepat guna dan tepat sasaran sesuai dengan fungsinya. ${ }^{19}$ Banyak hal baik dan positif yang dapat dilakukan dengan media komunikasi sosial, seperti diinspirasi nabi Yesaya lewat permenungannya, yakni agar ia dapat memberi semangat baru kepada orang yang letih lesu. Media komunikasi sosial, karenanya, bisa menjadi sarana pewartaan yang efektif, bukan untuk menghujat atau memfitnah, melainkan untuk menghadirkan kasih dan damai, untuk saling menyemangati di antara umat manusia.

Berkata-kata adalah suatu bentuk pengungkapan pendapat atau isi hati yang mudah dan dimaksud untuk membangun relasi yang baik dengan orang lain. Akan tetapi, ketidakmampuan untuk mengekang lidah mengakibatkan bahaya melegitimasi pertikaian dan kekerasan yang 
sifatnya menghancurkan. Paulus mengingatkan, "Jangan ada perkataan kotor keluar dari mulut kita, tetapi perkataan baik yang membangun dan bagi yang mendengar, beroleh kasih karunia" (Ef. 4:29). Perkataan kotor yang dimaksud Paulus juga mengacu pada perkataan yang jahat dan buruk, yang menjadi titik awal kemarahan, yang dapat memporakporandakan dunia dan kehidupan banyak orang. Perkataan kotor juga bisa berarti perkataan sia-sia yang dikeluarkan mulut manusia tanpa memikirkan efek sampingnya. Perkataan sia-sia, misalnya, berupa fitnah, yaitu perkataan yang tidak didasari kebenaran dan sengaja disebarkan (sebagai hoaks) yang akan mempersulit keadaan orang lain. Perkataan sia-sia adalah perkataan yang tidak berdaya transformatif pada diri seseorang, melainkan cenderung menghasut untuk mendatangkan maut terhadap orang lain.

Hoaks juga berarti tindakan berdusta dan ini erat korelasinya dengan salah satu dari Sepuluh Perintah Allah: "Jangan mengucapkan saksi dusta terhadap sesamamu" (Kel. 20:16). Berdusta adalah menyatakan sesuatu yang tidak benar dengan sengaja. Agustinus dengan keras mengecam orang yang menyebarkan kebohongan, dan mengatakan bahwa seorang pendusta adalah pendosa. Berdusta sama halnya dengan mengurangi kesempatan diri sendiri untuk mengalami kehidupan abadi kelak. Di sisi lain, Agustinus juga memahami bila kebohongan dilakukan demi kebaikan orang lain. Tindakan bohong dapat dilacak melalui pikiran dan motivasi seseorang, sehingga jika motivasinya adalah baik, yakni untuk membantu sesama, ini tidak dikategorikan sebagai dosa. ${ }^{20}$ Akan tetapi, dengan sudut pandang ini, kebohongan tidak lantas bisa dianggap sebagai hal yang biasa. Thomas Aquinas dalam menjelaskan doktrin Katolik menekankan bahwa berbohong adalah tindakan yang berlawanan dengan kemurnian Tuhan, karena tindakan itu mengaburkan kebenaran. Dusta secara alamiah tidak hanya menentang keutamaan kemurnian, tetapi juga menentang iman dan agama. $^{21}$

Karena sifatnya hanya menguntungkan diri atau kelompok tertentu, inkonsistensi dalam tuturan akan selalu menyiratkan intensi provokatif. Dalam konteks teologi-biblis, tindakan seperti itu adalah tindakan dosa. Tindakan berbohong dalam tuturan bisa menimbulkan pertikaian SARA (suku, agama, ras, dan agama) yang mengancam kehidupan bersama. Dalam Injil Matius, Yesus mengingatkan, “Oleh karena itu katakan ya kalau 
ya, dan katakan tidak kalau tidak" (Mat. 5:37). Agustinus mempertegas dengan permenungannya:

"But every liar says the opposite of what he thinks in his heart, with purpose to deceive. Now it is evident that speech was given to man, not that men might therewith deceive one another, but that one man might make known his thoughts to another. To use speech, then, for the purpose of deception, and not for its appointed end, is a $\sin$ "22

Komunikasi sosial dapat berkembang sebagai hasil dan kreativitas manusia atas izin Allah. Perkembangan teknologi informasi yang terjadi kini memberi sumbangan yang sangat besar jika dipergunakan sesuai fungsi dan tujuannya dengan tepat. Teknologi adalah produk dan gambaran kejeniusan manusia. Oleh karenanya, teknologi tidak perlu dipandang sebagai kekuatan 'asing' atau 'musuh' bagi manusia, melainkan hasil penemuan manusia yang patut disyukuri dan diapresiasi. Paus Fransiskus mengajak umat kristiani untuk bersukacita atas kemajuan ini dan bersemangat dalam tanggung jawab moral, agar dapat mengarahkan dengan baik teknosains ini sehingga menjadi sarana yang sungguh berharga untuk meningkatkan kualitas kehidupan manusia. ${ }^{23}$

Perkembangan teknologi informasi dapat membantu menyediakan pelayanan yang serba cepat bagi manusia khususnya karena informasi mudah didapatkan di manapun dan kapanpun. Ini merupakan atmosfer kesegaran yang dimunculkan oleh teknologi informasi, yakni kesegaran dalam kemudahan karena lewat telepon pintar orang mudah mengakses dan mendapatkan setiap informasi. Dengan demikian, di era keterbukaan informasi, orang dengan kecekatan budi mesti mampu menyaring setiap informasi untuk menampung dan menyebarkan berita yang baik dan benar. Tujuannya ialah membangun peradaban aman dan damai sebagai bentuk tanggung jawab manusia sebagai pewarta Kerajaan Allah. ${ }^{24}$ Dokumen Inter Mirifica menekankan tanggung jawab moral manusia dalam menerima dan menyiarkan berita melalui media teknologi informasi. Dalam hal ini, untuk mengetahui kebenaran sebuah berita, dibutuhkan daya nalar mendalam, yakni kecermatan mengindahkan keadilan serta cinta kasih lewat pertimbangan situasi terkait tujuan, orang-orang, tempat, waktu dan lain sebagainya. ${ }^{25}$ 
Di Indonesia, indikasi terjadinya degradasi nilai dalam ruangruang publik semakin menguat akhir-akhir ini. Ada kasus-kasus pencemaran nama baik, ujaran kebencian (bate speech), penyebaran hoaks, provokasi, penyebaran konten vulgar, dan lain sebagainya. Gejala-gejala ini menunjukkan makin kaburnya nilai-nilai moral, sehingga para pelahap dan penyebar informasi tidak mampu membedakan berita yang baik dan yang buruk, yang benar dan yang tidak benar. Banyak orang kini kurang memperhatikan etika, budaya, dan spiritualitas yang bisa menetapkan batas-batas dan pengendalian diri yang jernih. Hal ini juga digarisbawahi oleh Paus Fransiskus dalam ensiklik Laudato Si (2015) tentang kemajuan teknologi yang belum tentu sebanding dengan kemajuan etika dan penanaman nilai-nilai. Ia mengatakan bahwa "manusia modern belum menerima pendidikan untuk menggunakan kekuasaannya dengan baik." Oleh karenanya, tanpa etika dan norma, teknologi informasi hanya akan digunakan sesuai dengan kecenderungan manusiawi yang bebas, tetapi tidak bertanggung jawab.

Kecenderungan manusia modern yang bersikap acuh tak acuh terhadap etika berkomunikasi juga mencerminkan situasi polemis, karena nilai-nilai asali manusia, termasuk nilai religius, mengalami degradasi. Akibatnya, ada orang yang menggunakan teknologi informasi dengan cara yang salah, yakni untuk menyebarkan berita-berita bohong yang meresahkan banyak orang. Sementara itu, ada pula oknum yang bahkan merasa bangga karena telah menjadi penyebar berita bohong yang meresahkan publik. Terkait dengan gejala-gejala di atas, hoaks dapat dengan cepat membakar kemarahan orang atau kelompok tertentu yang kemudian menyulut kerusuhan dan kekacauan. Hoaks sering disebarkan dalam tampilan menarik, dikonstruksi dengan kepiawaian manipulasi data serta gambar untuk menggiring massa sampai pada tingkat keyakinan tertentu, sehingga apa yang dilihat, didengar, dan ditangkap seakanakan adalah fakta. Hal ini bisa menciptakan kecemasan dan keresahan pada masyarakat, dan yang sekaligus juga menciptakan disrupsi yang mengancam kehidupan bersama manusia. Lance Bennett dan Steven Livingstone merangkum telaah bahwa penyebaran berita bohong (fake news) berarti merusak nilai-nilai demokrasi, menimbulkan keresahan dan ketakutan publik serta disrupsi publik. ${ }^{26}$ Menyebarkan informasi bohong bukan hanya merusak tatanan publik, tetapi juga mengkhianati

\section{5}


iman, sebab pelaku agama seharusnya adalah pelaku kebenaran. Orang beriman mempunyai tanggung jawab untuk menyebarkan hanya beritaberita yang benar. Oleh karena itu, teknologi seharusnya digunakan untuk menyebarkan kebenaran dan kebaikan, seperti gambaran dari Jen Schradie bahwa menyebarkan informasi adalah sama seperti mewartakan Sabda Allah. Orang Kristen mesti menjadi pewarta kebenaran, sebab kebenaran adalah Kabar Baik yang akan menggembirakan banyak orang. ${ }^{27}$

\section{"Rekam, Unggah, Bagikan"}

Berkaitan dengan generasi milenial, salah satu pengaruh perkembangan teknologi informasi terhadap karakter generasi ini adalah keinginan untuk memproses dan memperoleh hasil yang serba cepat. Keinginan mendapat "apapun dengan serba cepat" tersebut mendorong generasi ini mengerjakan sesuatu sesuai kemampuan mereka. Sifat ini membuat generasi milenial seolah-olah cepat berpindah minat. ${ }^{28}$ Masyarakat hidup dengan limpahan informasi (pengetahuan) serta dengan cepat dan mudah mengambil serta menyebarkannya, sehingga terbangun pola pikir 'instan'. Karena mentalitas ini, banyak berita yang beredar pun mudah dan bahkan sengaja dimanipulasi kebenarannya dalam proses penyebaran. Di zaman ini, masih ada orang yang menghargai proses, tetapi kurang kritis karena dibungkus motivasi mendapat hasil serba cepat demi suatu tujuan. Kematangan berpikir untuk mempertimbangkan segala hal yang baru masih kurang.

Digitalisasi telah mengubah cara berkomunikasi dan interaksi, dan salah satu perubahan yaitu cara berbagi (sharing). Orang tidak semata-mata mengalami segala sesuatu, tetapi terlibat lebih jauh dalam mempublikasikan informasi atau berita. Orang tidak semata-mata melihat peristiwa, tetapi turut aktif membagikannya. Orang tidak hanya mengetahui suatu informasi, tetapi aktif meneruskannya semudah mengklik layar gawainya. Ini adalah salah satu mentalitas yang merebak, seperti dikatakan Yuval Noah Harari dalam bukunya Homo Deus: A Brief History of Tomorrow. Ia berpandangan bahwa menulis di buku harian pribadi (kemampuan reflektif) adalah praktik umum humanis pada generasi terdahulu ${ }^{29}$ yang dirasa tidak berguna bagi kaum muda kini. ${ }^{30}$ Harari mengatakan,

"Jika Anda pergi ke India dan melihat seekor gajah, Anda tidak memperhatikannya dan bertanya kepada diri sendiri 'Apa yang saya rasakan?' Anda terlalu sibuk mencari telepon pintar, mengambil gambar 
gajah itu, mengunggahnya ke Facebook dan kemudian memeriksa akun Anda setiap beberapa menit untuk melihat berapa banyak 'like' yang Anda dapatkan. Motto yang baru adalah "Jika Anda mengalami sesuatu, rekam. Jika Anda mengalami sesuatu, unggah. Jika Anda mengunggah sesuatu, bagikan." Kaum datais percaya bahwa pengalaman tidak berguna jika tidak dibagi, dan bahwa kita tidak perlu bahkan tidak bisa mencari makna dalam diri kita. Kita hanya perlu merekam, melihat sekilas (atau hanya judulnya) dan menghubungkannya pada aliran data besar, yakni membagikan lewat media sosial." 31

Perlu diwaspadai bahwa tampaknya banyak kasus penyebaran berita bohong akhir-akhir ini berasal dari kalangan generasi muda. Kenyataan lain yang bisa diamati yakni bahwa passion adalah kata kunci bagi generasi milenial. Mereka memilih pekerjaan yang sesuai passion mereka, dan setelahnya, mereka tidak ragu-ragu untuk memberikan seluruh kemampuan mereka. ${ }^{32}$ Akan tetapi, terkait informasi yang beredar di dunia maya, passion tampaknya justru kurang dibudidayakan, mengingat keseriusan dan kedalaman membaca dan menganalisis informasi cenderung minimalistis. Kebenaran suatu informasi acap kali dibaca bukan secara rasional, dengan sepenuh perhatian diri, tetapi secara emosional, yakni bergantung pada kesukaan atau ketidaksukaan, lebih daripada dianalisis kebenaran serta kegunaannya.

\section{Rekonstruksi Nalar Manusia}

"Internetisasi" segala macam aspek kehidupan manusia pada saat ini memiliki dampak serius pada cara manusia menerima kebenaran. Sebelum dunia dikepung oleh kekuatan internet, manusia berlombalomba mencari pengetahuan dengan cara saling menguji dan mengkritisi, sebab informasi masih sulit untuk didapatkan. Setelah internet hadir, manusia dihadapkan pada keberlimpahan informasi. Pesan gambar ('meme') berantai memenuhi dan menjejali media sosial. Akibatnya, orang cenderung lalai dalam memilah-milah informasi. Nalar kritis seakan-akan 'dimandulkan' oleh segala macam kemudahan yang ditawarkan internet. Dalam situasi ini perlu usaha untuk merekonstruksi nalar manusia. Ketika dunia teknologi menawarkan banyak latihan atau petunjuk praktis yang bisa memperkaya pengetahuan dan kreativitas, orang membutuhkan daya nalar untuk menyaring berita dengan kritis. Nalar kritis adalah potensi dasar untuk memperjelas setiap informasi. Keseriusan berpikir adalah 
salah satu solusi mengatasi kedangkalan pemahaman informasi. Menurut Iwan Pranoto, masa depan negara ini bergantung pada kemerdekaan anakanak untuk berpikir. ${ }^{33}$ Critical thinking merupakan salah satu kemampuan yang bisa digunakan untuk mengolah informasi menjadi pengetahuan, dan terutama membantu orang untuk mencapai kebenaran setiap informasi. Dengan kata lain, berpikir kritis akan membantu orang mengkaji atau menganalisis setiap informasi secara mendalam. Dengan cara berpikir ini, orang akan terbantu untuk 'mencurigai' (to reflect sceptically) setiap informasi yang sedang merebak dengan membangkitkan kegiatan berpikir secara mendalam (the ability to think in a reasoned way). ${ }^{34}$

Oleh karenanya, adalah penting membangun "kultur hidup" yang berbeda, artinya, membangkitkan "rasa penasaran" sebagai sebuah "kebiasaan berpikir" yang berpotensi menyaring setiap informasi. Dengan kegiatan berpikir kritis, wawasan seseorang akan diperdalam dan horizonnya diperluas karena berhadapan dengan beragam fenomena yang merangsang indra. Proses ini bukan hanya memperkokoh argumen, tetapi juga menumbuhkan kebijaksanaan praktis seseorang. Kemajuan teknologi memiliki arus yang berbeda, karena tidak mendengarkan suara hati, melainkan hendak mengendalikannya. Oleh sebab itu, daya nalar kognitif dan afektif perlu dikembangkan secara seimbang. Teknologi berpotensi memunculkan loncatan-loncatan perkembangan yang sangat cepat. Perkembangan itu bisa menjadi dorongan agar orang mensistematisasi daya nalar yang bisa membantu untuk memilih keterampilan yang sesuai dengan kebutuhan zaman.

Kemajuan teknologi bukan untuk dikhawatirkan, tetapi dimanfaatkan kekayaannya. Orang perlu menciptakan ruang agar perkembangan teknologi dapat relevan dengan dunia manusia dalam menciptakan sesuatu yang baru. Untuk menghadirkan sesuatu yang baru, orang bisa merekayasa teknologi agar sesuai dengan kemanusiaan. Merekayasa ulang dalam hal ini berarti mengungkapkan kebenaran suatu informasi melalui sumber-sumber yang sahih dan mendukung. Validitas setiap informasi terletak pada kejelian pikiran dan hati manusia untuk mencari tahu, maka kewajiban utama para penerima komunikasi sosial ialah membeda-bedakan dan bersikap selektif. ${ }^{35}$ Dengan demikian, peran semua orang, baik komunikator maupun penerima komunikasi, ialah memperhatikan etika dalam berkomunikasi. Etika berkomunikasi ini akan 
menentukan disposisi pribadi seseorang dalam menggunakan teknologi komunikasi dalam keseharian hidupnya.

\section{Etika dalam Komunikasi}

Umat kristiani hidup dalam masyarakat berbasis informasi yang melimpahinya tanpa pandang bulu dengan data, dan semua diperlakukan sama pentingnya, dan yang mengarah ke kedangkalan di bidang diskresi moral. Oleh karena itu, untuk menanggapi situasi ini perlu diberikan pendidikan yang mengajarkan cara berpikir kritis serta mendalam, dan yang mendorong pengembangan nilai-nilai moral yang dewasa. ${ }^{36}$ Kebaikan yang besar dan juga kejahatan yang besar berasal dari cara orang menggunakan media komunikasi. Sarana komunikasi sosial, bila digunakan dengan tepat, dapat membantu untuk menciptakan dan mendukung suatu komunitas manusiawi yang berdasarkan keadilan dan kasih. ${ }^{37}$ Sebaliknya, jika salah digunakan, akan merusak tatanan sosial dan menciptakan polusi pada kesejahteraan pribadi dan masyarakat. Singkatnya, sakralitas diri seseorang dapat juga ditentukan oleh media sosial, yakni ketika dipakai sebagai sarana untuk mewartakan kebaikan dan kebenaran.

Potensi desakralisasi akan menguat apabila media sosial digunakan untuk mencemarkan diri dan masyarakat dengan manipulasi informasi. Sebaliknya, penggunaan media sosial untuk membagikan informasi yang membangun dan berguna bagi banyak orang adalah salah satu langkah pengudusan diri. Persoalan mendasar ini menyangkut semua orang yang adalah para pelaku informasi. Banjir informasi meliputi berita-berita berat ataupun hiburan, yang berupa doa ataupun pornografi, yang berupa renungan atau juga berisi kekerasan. Mengingat beragamnya informasi yang mengalir di dunia media sosial, adalah kewajiban orang untuk mencermati secara kritis. Berkaitan dengan moralitas, tindakan pengudusan diri melalui media sosial adalah tanggung jawab pribadi, karena tergantung pada keputusan individu dalam mengolah dan mengkaji serta menyebarkan informasi. Pengalaman bermedia dapat membantu pelaku informasi untuk bukan hanya berperan sebagai penikmat informasi, tetapi terlibat dalam proses secara kritis untuk menghadirkan kebenaran informasi.

Perkembangan teknologi informasi yang dahsyat telah meningkatkan kemampuan berkomunikasi sebagian orang dan kelompok yang beruntung, namun secara paradoksal kekuatan-kekuatan yang 
dapat mengantar pada komunikasi lebih baik juga dapat meningkatkan pengasingan dan pemusatan pada (kepentingan) diri. ${ }^{38}$ Salah satu ekses ialah secara sengaja memanipulasi suatu informasi untuk memancing tanggapan pengguna internet sekaligus menciptakan keresahan pada publik. Menyebarkan berita bohong termasuk dalam kategori "terorisme siber" karena tindakan itu ibarat senjata perang yang dapat menimbulkan amarah dan berpotensi menghilangkan nyawa seseorang atau menghancurkan kelompok tertentu. ${ }^{39}$

Pembinaan kepribadian dan suara hati, penafsiran dan penataan hubungan afektif, penyusunan tahap-tahap pendidikan dan pembinaan, pengembangan dan penyebaran peristiwa-peristiwa kultural, serta pengembangan kehidupan politik, sosial, dan ekonomi merupakan hal-hal penting yang perlu dikembangkan di era banjir informasi ini. Media massa dapat dan harus memajukan keadilan dan solidaritas sesuai dengan visi organik yang benar tentang pengembangan manusia, dengan pemberitaan secara tepat dan benar, analisis situasi dan masalah secara lengkap, dan penyediaan forum untuk berbagai macam pandangan. Pendekatan lewat etika yang autentik dalam penggunaan media komunikasi harus ditempatkan dalam konteks pelaksanaan kebebasan dan tanggung jawab yang matang, berdasarkan kriteria tertinggi kebenaran dan keadilan. ${ }^{40}$

Selain pembinaan kolektif yang sangat menentukan untuk mencapai level penyiaran informasi yang benar yang tak diragukan kebenarannya, ada hal lain yang penting bagi umat kristiani, yakni kesadaran pribadi untuk memohon pada kehendak ilahi supaya menjadi agen pewarta Allah yang menyelamatkan, melalui media sosial. Inspirasi biblisnya bisa ditemukan dalam kisah ketika para murid meminta kepada Yesus agar mengajar mereka berdoa (Luk. 11:1). Umat kristiani dapat juga memohon kepada Tuhan agar mencapai kekudusan dengan cara membangun komunikasi yang baik dengan Tuhan dan dengan sesama melalui media komunikasi. Dalam cakrawala yang baru, media sosial menghadirkan berbagai kekayaan yang dapat diakses untuk menambah wawasan demi menentukan valid tidaknya suatu informasi. Jika informasi adalah benar dan berguna bagi pribadi, umat kristiani bisa menjadi saluran berkat yang membebaskan sesama dari kemiskinan informasi dengan cara menyebarkan kebenaran informasi tersebut. Komunikasi harus dipenuhi dengan kebenaran, karena sifat kebenaran adalah hakiki untuk kebebasan individu dan untuk mewujudkan komunitas yang otentik pribadi-pribadi. ${ }^{41}$ 
Moralitas yang diterangi iman akan membuat orang mampu membedakan apa yang baik (dan membangun) serta apa yang jahat (dan bisa meresahkan banyak orang).

\section{Nabi yang Mewartakan "Alam Kodrat yang Baik"}

Dalam Kitab Suci Perjanjian Lama dikenal nabi sejati yang dilawankan dengan nabi palsu. ${ }^{42}$ Nabi sejati berbicara dalam nama Allah dan menyampaikan apa yang disabdakan Allah demi keselamatan umat yang dikasihi Allah. Sementara itu, nabi palsu mengatasnamakan Allah walaupun tidak diutus oleh Allah. Mereka berbicara tentang sesuatu hal bukan berdasarkan Sabda Allah, tetapi berdasarkan kepentingan mereka sendiri. Oleh karenanya, rakyat yang mendengarkan nabi palsu pun akan hidup dalam kepalsuan. Nabi palsu adalah pembual, ibarat penyebar hoaks di masa kini. Hoaks kini merajalela di semua bidang kehidupan manusia karena internet. Para komunikator kristiani mempunyai suatu tugas kenabian, yakni suatu panggilan untuk berbicara melawan dewadewa palsu yang merintangi semua orang untuk melihat kebenaran moral berdasarkan martabat manusia dan hak-haknya. ${ }^{43}$ Paulus dalam suratsuratnya menasihati jemaat untuk tetap menjaga hati dan pikiran, tindakan dan perbuatan, khususnya untuk tidak menyakiti hati sesama dan Tuhan, sebab tindakan yang bercacat (salah satunya, menyebarkan kabar buruk kepada sesama) adalah tindakan kejahatan yang menodai kebenaran.

Dalam surat Paulus kepada jemaat di Roma 1:18, kejahatan dijelaskan sebagai penindasan terhadap kebenaran. Lewat nubuat tentang kedatangan pendurhaka, Paulus menunjukkan bahwa orang-orang mudah disesatkan "karena tidak menerima dan mengasihi kebenaran"(2Tes. 2:10). Itulah sebabnya Allah mendatangkan kesesatan atas mereka yang menyebabkan orang percaya pada dusta (2Tes. 2:11-12). Murka Allah dinyatakan kepada mereka yang tidak taat kepada kebenaran (Rm. 2:28), tetapi Allah menghendaki supaya semua orang memperoleh pengetahuan tentang kebenaran (1Tim. 2:4). Nabi sejati akan berupaya untuk membimbing orang supaya bertobat dan mengenal kebenaran (2Tim. 2:25). Sementara itu, nabi palsu yang menyebarkan dongeng-dongeng adalah orang yang telah berpaling dari kebenaran (Tit. 1:14). ${ }^{44}$

Jean-Jacques Rousseau pernah menegaskan bahwa perkembangan teknologi telah mencederai kodrat manusia yang pada mulanya baik, 
dan merayu manusia untuk melakukan segala macam kebejatan. Bila manusia ingin selamat, hanya ada satu jalan, yakni "back to nature", kembali kepada keadaan semula. ${ }^{45}$ Kembali pada keadaan semula bisa berarti mengembangkan sesuatu yang berbeda dari gejala komunal yang merebak. Ini bisa dilakukan secara pribadi lewat kesadaran diri dan secara kolektif lewat kesadaran bersama untuk menciptakan gerakan melawan hoaks. Banyak oknum sibuk menyebarkan berita yang cacat dan kotor, maka orang harus berada di posisi sebaliknya, yakni mampu menyebarkan sukacita kebenaran dalam kata-kata meneguhkan lewat media sosial. Ini bisa dikaitkan dengan dengan ungkapan Marcus Aurelius, "Kalau saya melakukan sesuatu, hendaklah saya melakukannya demi kebaikan manusia". Kebahagiaan manusia ialah "dengan mengingat Tuhan, dari satu perbuatan sosial beralih ke perbuatan sosial berikutnya". ${ }^{46}$

\section{Berkomunikasi dengan Daya Roh Kudus}

Tantangan besar zaman ini bagi umat beriman dan semua orang yang berkehendak baik adalah mempertahankan komunikasi yang jujur dan bebas, yang membantu memperkuat kemajuan dunia. Setiap orang mesti mengetahui bagaimana memelihara peneguhan rohani yang penuh perhatian dan kesiagaan, dengan mengembangkan kemampuan bersikap kritis yang sehat melalui daya persuasi di media komunikasi. Orang beriman harus mengandalkan bantuan Roh Kudus, sebab bantuan-Nya akan mengarahkan dalam menimbang dan mengkritisi setiap informasi yang selalu mengalir di media sosial. Proses membaca secara kritis dengan bantuan Roh Kudus akan melatih umat beriman untuk peka pada rangsangan kebenaran, sehingga apa yang diwartakan dan dibagikan adalah kebenaran itu sendiri. Mewartakan kebenaran berarti mewartakan kasih Allah, sebab hanya dalam kebenaran, kasih memancarkan cahaya. ${ }^{47}$

Dalam sejarah keselamatan, Kristus menampilkan diri-Nya kepada manusia sebagai 'komunikator' Bapa, seperti dituliskan, “Allah, pada zaman akhir ini, telah berbicara kepada manusia dengan perantaraan Putra-Nya" (Ibr. 1:2). Sang Putra itu mengkomunikasikan kepada manusia senantiasa kasih Bapa dan makna terdalam kehidupan manusia. Selama ada di dunia ini, Kristus mewahyukan diri-Nya sebagai komunikator yang sempurna. Lewat penjelmaan-Nya, Ia sepenuhnya menempatkan diriNya setara dengan mereka yang harus menerima komunikasi-Nya, dan Ia 
memberikan pesan bukan hanya dengan kata-kata, tapi dalam seluruh cara hidup-Nya. Ia berbicara "dari dalam", yakni dari desakan umat-Nya, dan mewartakan pesan ilahi tanpa rasa takut atau keinginan berkompromi. Ia menyesuaikan diri dengan cara bicara umat-Nya dan pola pikir mereka, dan Ia berbicara mengenai tanda-tanda zaman. ${ }^{48}$ Yesus adalah model sekaligus standar dalam berkomunikasi, baik bagi para jurnalis ataupun penerima informasi. Yesus mengajarkan bahwa komunikasi adalah suatu tindakan moral, yang dijelaskan-Nya dengan mengatakan,

"Orangyang baik mengeluarkan hal-hal yang baik dari perbendaharaannya yang baik, dan orang yang jahat mengeluarkan hal-hal yang jahat dari perbendaharaannya yang jahat. Tetapi Aku berkata kepadamu: setiap kata sia-sia yang diucapkan orang harus dipertanggungjawabkannya pada hari penghakiman. Karena menurut ucapanmu engkau akan dibenarkan, dan menurut ucapanmu pula engkau akan dihukum" (Mat 12:35-37).

\section{Kedamaian adalah Berita Sejati}

Menyebarkan suatu berita lewat media sosial sama halnya dengan menyebarkan pengetahuan dan pengertian yang dapat membentuk serta meneguhkan kepribadian banyak orang. Agustinus pernah membuat sintesis gagasan tentang 'pengertian' dan “menjadi teguh" ini dalam Pengakuan-Pengakuan-nya, yakni ketika dia berbicara tentang kebenaran yang bisa diandalkan agar orang bisa berdiri dengan teguh. ${ }^{49}$ Dengan kata lain, manusia membutuhkan kebenaran, sebab tanpa kebenaran manusia tidak mampu berdiri teguh dan bergerak maju. Dengan demikian, mengkomunikasikan sesuatu yang baik dan benar akan sangat berguna dan meneguhkan banyak orang. Setiap informasi yang disebarluaskan bisa menjadi kabar sukacita jika informasi itu berdiri pada pijakan kebenaran. Ini merupakan tanggung jawab setiap orang beriman yang sadar dan tahu tentang martabat dirinya sebagai manusia yang diciptakan sesuai gambar Allah. Mengakui diri sebagai makhluk religius berarti mengamalkan kehidupan yang baik secara vertikal dan horizontal. Mencintai Allah berarti memiliki tanggung jawab pula untuk mencintai sesama. Menyebarkan sesuatu yang baik kepada sesama, dalam hal ini, adalah tindakan untuk merealisasikan cinta Allah kepada dunia. Pernyataan cinta yang real ini merupakan suatu tindakan pengudusan diri dan pembentukan kekudusan bagi sesama, suatu proses sakralisasi, sebab kasih Allah harus diwujudkan dalam bentuk perhatian kepada sesama manusia. ${ }^{50}$ 
Yesus adalah teladan komunikator yang baik bagi umat kristiani, dan juga bagi umat manusia. Pewartaan tentang kebenaran Allah yang menyelamatkan umat manusia lewat penderitaan yang tragis dan dramatis, dan juga kebangkitan-Nya adalah panggilan untuk mewartakan kebenaran. Lewat perkataan dan tindakan-Nya, Yesus mengubah manusia menjadi manusia baru yang penuh kasih. Kehidupan baru dalam Kristus adalah jaminan bagi setiap orang Kristen untuk menyalurkan kebenaran sebagai wujud kasih kepada Allah. Di era digital, hal ini dapat dipandang sebagai tindakan profetis, yakni keberanian bersaksi (mewartakan) secara jujur kepada sesama melalui kesaksian pengudusan diri.

\section{Simpulan}

Dalam Kristianitas, kebenaran bukan hanya realitas konseptual yang menjadi kriteria bagaimana orang menilai sesuatu serta mendefinisikannya sebagai benar atau salah. Kebenaran adalah panggilan yang melibatkan seluruh kehidupan seseorang, yang akan menjadi praxis kehidupan iman. Secara biblis dikatakan bahwa kebenaran membawa dukungan, soliditas, dan kepercayaan sebagaimana tersirat dalam kata 'Amin', suatu ungkapan liturgis yang berakar pada kata 'aman'. Dalam pengertian relasional iman, satu-satunya sumber kebenaran yang dapat diandalkan dan dapat dipercaya adalah Allah, yang pewahyuannya ditemukan dalam perkataan Kristus, "Akulah Kebenaran" (Yoh. 14:6). Kebenaran akan menjadi sebuah praxis ketika direfleksikan dan dihidupi sehingga pada akhirnya akan memerdekakan seseorang (Yoh. 8:32).

Hoaks menyimpan potensi destruktif terhadap nilai-nilai luhur kemanusiaan, salah satunya, menghancurkan kecintaan pada kebenaran. Kecintaan pada kebenaran akan menjadi sesuatu yang jauh dan tidak terjangkau apabila praxis kehidupan iman terkikis oleh kebohongan dan manipulasi. Jika mentalitas buruk itu menjadi kebiasaan yang dibiarkan, kehidupan tinggal merupakan perkara nafsu dan kesenangan yang tidak memedulikan keluhuran martabat manusia, yang berakibat pada terciptanya jarak antara manusia dan sesama, namun lebih-lebih antara manusia dan Sang Pencipta. Semua orang, dan khususnya umat kristiani, mesti berpegang teguh pada perintah dan kebenaran Allah sebagai penopang utama kehidupan. Allah adalah sumber iman yang memampukan setiap 
orang untuk terus-menerus berjuang menyuarakan dan mencintai kebenaran di tengah berbagai paradoks, ambigiutas, dan inkonsistensi peradaban. Paulus menegaskan, "Jika Allah di pihak kita, siapakah yang akan melawan kita” (Rm. 8:31).

Disposisi batin dalam komunikasi kristiani seperti ditelaah di atas memungkinkan setiap pribadi yang hidup di tengah dunia yang serba cepat, labil, dan agresif karena "banjir informasi", tetap mampu bersaksi tentang kekudusan, dengan sikap sabar dan teguh di dalam kebaikan seperti kehidupan para kudus. Umat beriman tidak akan membuangbuang energi dengan sekadar mengeluh tentang kerapuhan sesamanya dan akan menghindari segala bentuk kekerasan verbal yang menghancurkan dan memperlakukan sesama dengan buruk. Sikap pengekangan diri untuk mengedepankan orang lain akan dipraktikkan, dan ini adalah bagian dari kedalaman refleksi perendahan-diri agar mampu menghayati kesabaran dan keteguhan untuk bertindak dalam kebenaran. Dalam konteks komunikasi kristiani, melawan hoaks di media sosial dan berpikir kritis dalam kebenaran adalah wujud partisipasi dalam komunikasi Allah kepada dunia dan panggilan manusia menuju kekudusan diri.

\section{References:}

Ahyad, Ade \& Donna Widjajanto. Smart Millenials. Jakarta: PT Gramedia Pustaka Utama, 2016.

Alimi, Moh. Yasir. Mediatisasi Agama Post-Truth dan Ketahanan Nasional. Yogyakarta: LKiS, 2018.

Azzahra, Putri. Explore: 20 Kisah Perantau Ilmu. Jakarta: Elex Media Komputindo, 2017.

Blommendaal, J. Pengantar kepada Perjanjian Lama. Jakarta: Gunung Mulia, 2008.

Bok, Sissela. Lying: Moral Choice in Public and Private Life. New York: Vintage Books, 1978.

Cottrell, Stella. Critical Thinking Skills: Effective Analysis, Argument and Reflections. Basingstoke: Palgrave Macmillan, 2017.

Farkas, Johan \& Schou, Jannick. Post-Truth, Fake News and Democracy:

Mapping the Politics of Falsehood. New York: Routledge, 2019. 
Guthrie, Donald. Teologi Perjanjian Baru I: Allah, Manusia, Kristus. Jakarta: Gunung Mulia, 2008.

Harari, Yuval Noah. Homo Deus: Masa Depan Umat Manusia. Jakarta: PT Pustaka Alvabet, 2015.

Mauludi, Sahrul. Seri Cerdas Hukum: Awas Hoax! Cerdas Menghadapi Pencemaran Nama Baik, Ujaran Kebencian \& Hoax. Jakarta: Elex Media Komputindo, 2018.

Nares, Roberts. A Glossary: or, Collection of Words, Phrases, Names, and Allusions to Customs, Proverbs, etc., which have been Thought to Require Illustration, in the Words of English Authors. London: Library of the University of Mighigan, 1822.

Putranto, C. "Iman Katolik Menghadapi Tantangan Jaman" dalam Ign. Bambang Sugiharto (Ed.), Agama Menghadapi Zaman. Jakarta: Asosiasi Perguruan Tinggi Katolik, 1992.

Schradie, Jen. The Revolution That Wasn't: How Digital Activism Favors Conservatives. London \& England: Harvard University Press, 2019.

Schultze, Quentin J. High-Tech Worship?: Using Presentational Technologies Wisely. United States of America: Baker Books, 2004.

Simarmata, Janner, et. al. Hoaks dan Media Sosial: Saring Sebelum Sharing (Medan: Yayasan Kita Menulis, 2019.

Sugirtharajah, Rasiah S. Wajah Yesus di Asia. Jakarta: Gunung Mulia, 2007. Tollefsen, Christopher O. Lying and Christian Ethics. New York, NY: Cambridge University Press, 2014.

Van der Weij, P. A. Filsuf- Filsuf Besar tentang Manusia. Jakarta: Gramedia, 1998.

Westermarck, Edward. Christianity and Morals. London, New York: Routledge, 2013.

Walsh, Lynda. Sins against Science: The Scientific Media Hoaxes of Poe, Twain, and Others. New York: State University, 2006.

\section{Endnotes:}

1 C. Putranto, "Iman Katolik Menghadapi Tantangan Jaman" dalam Ign. Bambang Sugiharto (Ed.), Agama Menghadapi Zaman (Jakarta: Asosiasi Perguruan Tinggi Katolik, 1992) 132.

2 Lih. Dewan Kepausan untuk Komunikasi Sosial, Gereja dan Internet: Etika dalam Internet (22 Februari 2002) dalam Seri Dokumen Gerejawi No. 111, Jakarta, 2019. 
3 Lih. Surat Apostolik Yohanes Paulus II, Perkembangan Cepat (24 Januari 2005) dalam Seri Dokumen Gerejawi No. 111, Jakarta, 2019.

4 Janner Simarmata, et. al., Hoaks dan Media Sosial, Saring Sebelum Sharing (Medan: Yayasan Kita Menulis, 2019) 13-14.

5 Moh. Yasir Alimi, Mediatisasi Agama Post-Truth dan Ketahanan Nasional (Yogyakarta: LKiS, 2018) 70.

6 Simarmata, op. cit., 14.

7 "April Mop" dikenal juga dengan istilah April Fool's Day pada setiap tanggal 1 April. Pada hari itu, orang dianggap boleh berbohong atau memberi lelucon kepada orang lain tanpa dianggap bersalah.

8 Paus Fransiskus, "Fake News and Journalism for Peace", pesan Paus untuk World Communications Day (24 Januari 2018) art. 1.

9 Robert Nares, A Glossary: or, Collection of Words, Phrases, Names, and Allusions to Customs, Proverbs, etc., which have been Thought to Require Illustration, in the Words of English Authors (London: Library of the University of Michigan, 1822) 373.

10 Frase ini menegaskan bahwa kebenaran itu hanya dapat dilihat dari perspektif iman.

11 Lynda Walsh, Sins against Science: The Scientific Media Hoaxes of Poe, Twain, and Others (New York: State University, 2006) 17.

12 Nurul Hidaya. A., et. al., "Pengaruh Media Sosial terhadap Penyebaran Hoax oleh Digital Native" (Januari 2019), https://www.researchgate.net/ publication/330135181 (access 11.06.2019).

13 Sahrul Mauludi, Seri Cerdas Hukum: Awas Hoax! Cerdas Menghadapi Pencemaran Nama Baik, Ujaran Kebencian \& Hoax (Jakarta: Elex Media Komputindo, 2018) 332.

14 Paus Fransiskus, "Fake News and Journalism for Peace", art. cit., art. 2

15 Paus Fransiskus, Gaudete et Exultate, diterjemahkan oleh Krispurwarna Cahyadi (Jakarta: Dokpen KWI, 2019) art. 115.

16 Christopher O. Tollefsen, Lying and Christian Ethics (United States: Cambridge University Press, 2014) 34.

17 Paus Fransiskus, Lumen Fidei, diterjemahkan oleh Krispurwarna Cahyadi (Jakarta: Dokpen KWI, 2018) art. 26.

18 Ibid.

19 Quentin J. Schultze, High-Tech Worship?: Using Presentational Technologies Wisely (United States of America: Baker Books, 2004) 63.

20 Edward Westermarck, Christianity and Morals (London, New York: Routledge, 2013) 307.

21 Ibid., 311.

22 Sissela Bok, Lying: Moral Choice in Public and Private Life (New York: Vintage Books, 1978) 45.

23 Lih. Paus Fransiskus, Laudato Si, diterjemahkan oleh Martin Harun (Jakarta: Obor, 2015) 78-79.

24 Paus Paulus VI, Inter Mirifica, dalam R. Hardawiryana (Penerjemah) Dokumen Konsili Vatikan II (Jakarta: Obor, 1993) art. 2.

25 Ibid., art. 4-5. 
26 Johan Farkas \& Jannick Schou, Post-Truth, Fake News, and Democracy: Mapping The Politics of Falsehood (New York: Routledge, 2019) 75.

27 Jen Schradie, The Revolution That Wasn't: How Digital Activism Favors Conservatives (London \& England: Harvard University Press, 2019) 166.

28 Ade Ahyad \& Donna Widjajanto, Smart Millenials (Jakarta: PT Gramedia Pustaka Utama, 2016) 7.

29 Kalangan humanis meyakini bahwa pengalaman terjadi dalam diri seseorang, dan bahwa ia harus menemukan dalam dirinya sendiri makna dari segala yang terjadi sehingga mengilhamkan makna bagi alam semesta.

30 Yuval Noah Harari, Homo Deus: Masa Depan Umat Manusia Jakarta: PT Pustaka Alvabet, 2015) 444-445.

31 Ibid., 445.

32 Ahyad \& Widjajanto, op. cit., 19.

33 Putri Azzahra, Explore: 20 Kisah Perantau Ilmu (Jakarta: Elex Media Komputindo, 2017) 159.

34 Stella Cottrell, Critical Thinking Skills: Effective Analysis, Argument and Reflections (Basingstoke: Palgrave Macmillan, 2017) 2.

35 Lih. Dokumentasi dan Penerangan KWI, Surat Paus Yohanes Paulus II kepada Para Artis dan Etika dalam Komunikasi (Jakarta: Dokpen KWI, 1999) art. 20.

36 Paus Fransiskus, Evangelii Gaudium, diterjemahkan oleh F.X. Adisusanto \& Bernadeta Harini Tri Prasasti (Jakarta: Dokpen KWI, 2014), art. 64.

37 Dokumentasi dan Penerangan KWI, Surat Paus Yohanes Paulus II kepada Para Artis dan Etika dalam Komunikasi, op. cit., art. 1.

38 Lih. Dewan Kepausan untuk Komunikasi Sosial, Etika dalam Internet, op. cit., art. 9

39 Ibid.

40 Lih. Surat Apostolik Paus Yohanes Paulus II, Perkembangan Cepat, op. cit., art. 3.

41 Ibid, art. 5.

42 Misalnya, Yer. 28 mengisahkan tentang nabi Hananya, seorang nabi palsu yang selalu bertengkar dengan nabi Yeremia; 1Raj. 22 menuliskan mengenai Mikha bin Yimla, seorang nabi benar, yang bertentangan dengan nabi-nabi palsu; lih. J. Blommendaal, Pengantar kepada Perjanjian Lama (Jakarta: Gunung Mulia, 2008) 105.

43 Surat Paus Yohanes Paulus II kepada para Artis dan Etika dalam Komunikasi, op. cit., art. 31.

44 Donald Guthrie, Teologi Perjanjian Baru I: Allah, Manusia, Kristus (Jakarta: Gunung Mulia, 2008) 222.

45 P. A. van der Weij, Filsuf-Filsuf Besar tentang Manusia (Jakarta: Gramedia, 1988) 81.

46 Ibid., 54.

47 Lih. Paus Benediktus XIV, Caritas In Veritate, diterjemahkan oleh B. R. Agung Prihartana (Jakarta: Dokpen KWI, 2014) art. 3.

48 Lih. Surat Apostolik Paus Yohanes Paulus II, Perkembangan Cepat, op. cit., art. 14.

49 Paus Fransiskus, Lumen Fidei, op. cit., art. 23.

50 Rasiah S. Sugirtharajah, Wajah Yesus di Asia (Jakarta: Gunung Mulia, 2007) 42. 